\title{
PDZK1 Gene
}

National Cancer Institute

\section{Source}

National Cancer Institute. PDZK1 Gene. NCI Thesaurus. Code C114322.

This gene plays a role in the regulation of protein localization. 